\title{
Education, Democracy and Digital Media
}

\author{
by Birte Hatlehol
}

\section{Social imaginations and digital representations, - a pedagogical method for education in democracy?}

The last years we have witnessed a growing worldwide interest in questions concerning education and democratic citizenship. There are particular anxieties about young people and their decreasing will to participate in democratic life. Research shows that there is a substantial decline in political interest and engagement among young people compared to the previous generation (Engelstad and Ødegård, 2003; Mikkelsen, 2001 and 2002; Buckingham, 2000; White et al, 2000).

In the report “Freedom's Children: Work, Relationships and Politics for $18-34$ YearOlds in Britain Today», Helen Wilkinson and Geoff Mulgan (1995) point to a historical, political and social disconnection of the younger generation in Europe. The report shows that frustrations, violence, and rejection of national identity are expanding. Young people do not feel part of the community. The Civic Education Study in Norway also shows that young people are increasingly less likely to vote, to join a party or to be politically active (Mikkelsen 2001, 2002). Therefore, as Wilkinson and Mulgan claim, the challenge is not as much to develop alternatives to conventional politics, but rather to find new ways to reconnect young people to politics.

David Buckingham of the London-based "Centre for the Study of Children, Youth and Media" asserts that young people are excluded from political discourses and decisions. Young people are often seen as lazier and as less socially responsible than adults. Provokingly, he asks: "Why should they bother to learn about something when they have no power to influence it, and when it makes no effort to address itself to them?" (Buckingham 2000:172).

On this background, the important question is; How to include and reconnect adolescents in politics?

Today most schools have "Citizenship Education" in their curricula. The political education in many Western countries focuses on democratic knowledge, skills and democratic values or attitudes. But these are preconditions for democracy and not democracy in itself. This means that the students do not learn to be the citizens of a democracy. The present education in democracy can therefore be seen as mostly a way to integrate children and adolescents in society. Ingerid Straume (2008) asserts that conceptions of democracy in the field of education are limited and "geared 
towards integration and peaceful coexistence" (Straume 2008:12). They learn how to live peacefully together, like in the programme "Learning and Living Democracy", which is part of the Council of Europe's programme, "Education for Democratic Citizenship and Human Rights" (2008). They do not learn to be active political citizens in a democratic State.

So in what ways would it be possible to change the education so that young people are reconnected to politics and supported in their development towards an active political citizenship?

Straume proposes politicization of the field and call attention to Cornelius Castoriadis' theories of democracy. He is inspired of the ancient Greek and builds his theories on how the Greeks created democracy. Castoriadis defines democracy as a regime of individual and collective autonomy (Castoriadis, CR 1997).

"An autonomous society, as a self-instituting and self-governing collectivity, presupposes the development of the capacity of all its members to participate in its reflective and deliberative activities. [...] Democracy in the full sense can be defined as the regime of collective reflectiveness" (Castoriadis WIF, 1997:132)

For Castoriadis a genuine democracy includes everybody in the decision making. In my interpretation this means that the younger generation should be included, and not excluded from politics. But in order to raise citizens capable of governing and of being governed, we need an education that supports the development of autonomy. In ancient Greece the citizens where educated when they participated as members of the democracy (Castoriadis, CR 1997). As a matter of fact, Norwegian laws include children and youth in some of the community's decision-making, especially with regard to the local environment. The law about city planning and buildings in the community states that the local authorities have to organize their planning process in a way that supports the participation of children and youth (Miljøverndepartementet 1995). This is a great opportunity to include children and youth in politics.

Unfortunately surveys shows that young people's experience is that their participation is symbolic and without real influence. This can be interpreted as a pseudo-democracy (Haugen 1995; Lidén 2003; Lidén and Ødegård 2002).

There are several reasons that children and youth are excluded, but one reason might be because of the way young people express themselves. In order to become a part of the daily political discussions taking place around you, one would normally have to speak the language of the adults, or the language of politics. However, younger people often express themselves differently than the older generation and find it difficult to articulate their thoughts the way adults do, with the result that they are excluded from the ongoing public debate. As a result, their views and opinions are not being heard and therefore have little political impact.

My challenge has been to find new ways to connect youth to politics that can support their autonomy. Children and adolescents use digital media in their daily lives. They 
are not only media consumers but media producers. The media have traditionally had an important role in the democracy. The Internet and new media technology can give a new contribution to the public space and democracy (Poster, 1995; Castells, 2001; Norris, 2001). The emergence of mass self-communication--e.g. blogs, podcasts, wikis, etc.- has raised new possibilities to produce and communicate media messages (Castells, 2007).

Why not use the media in the school for education in democracy? The digital media has great potentials to reconnect the youth to politics. In addition the media gives access to the public space and in that way the youth's expressions can have an impact. As part of my doctoral thesis, I have developed two projects in which high school students between 16 and 17 have created, produced, and presented different kinds of media texts, distributed on the Internet. They created digital stories, hypertexts and manipulated pictures. Their stories and self-expressions can be viewed at www.ungisentrum.net.

The objective for my two projects was to allow adolescents to articulate their views, their wishes, their opinions, and their thoughts on a specific subject and to express themselves through different media genres. Internet as a media provides an opportunity for adolescents to share their views with a large audience. Perhaps, digital media production is one method and an alternative "language", which could be utilized in schools in order to empower young people and make them more engaged and interested in the developments and discussions taking place around them in their daily environment. And perhaps, in this manner, the youth's expressions can have an impact on politics and even create new ways to participate in politics.

But most important, when expressing yourself you have to reflect, consider and think over what your point of view is. The time it takes to produce a multimodal media text allows the producer to think and reflect and even discuss with classmates, friends, parents and teachers. In the end, it can contribute to their emancipation and autonomy. To raise the consciousness among young people about society is an important and challenging task for the schools. Stories and storytelling are engaging and let people use their emotional intelligence and cognitive ability. Teachers have often been "busy" teaching the students to become critical, not at least in media education. But what counts as "critical consciousness"? And who defines it? Creative production can generate both new and more profound critical insights (Buckingham, 2003). Besides, society has a lot of challenges to deal with, where the need of fantasy and imaginations to find new solutions is substantial. As Cornelius Castoriadis says: "Imagination is the power (the capacity, the faculty) to make appear representations /.../ whether with or without an external incitement. In other words: imagination is the power to make be that which 'realiter' is not" (Castoriadis, CR 1997:322).

Cornelius Castoriadis' ideas about autonomy and social imaginary significations provided me with a new approach to these questions. As he writes: "[A]utonomy is the capacity to call into question the given institution of society" (Castoriadis, 2005:314). Through the active engagement of their imagination, the students can 
obtain consciousness about their own thoughts and viewpoints and, hopefully, increased autonomy-perhaps, even more power.

Dorothy Rowe defines power in this way: "In the final analysis, power is the right to have your own definition of reality prevail over other people's definition of reality" (Rowe, 1989:16). With other words; the power to define how other people should define (Rowe, 1991). This definition captures the usual power structure existing between children and adults (John, 2003). In connection with the new media, Gunther Kress (2003) says that we are not only dealing with a technological revolution, but also a social revolution. The new technology carries out a potential for radical social change, because new media implies a redistribution of semiotic power: the power to create and distribute meaning. This is consistent with Castoriadis' inspiration: Through producing multimodal media texts young people get the power to create and distribute social imaginations which can turn over to be significations in their society.

\section{About the projects}

The first project was developed during 4 weeks in 2003 and is about the development of a city centre; namely the city centre of Lillehammer in Norway. The local authorities were at the time about to make new 10-year development plans for the city, and made a survey where they asked a select group of citizens what they would want for their city in terms of development. The citizens invited to take part in this survey were mostly so-called "important" people associated with the local chamber of commerce, associations for the elderly, and so on. The community of Lillehammer was not very interested in listening to the views of young people, although they are using the city centre as much as the older citizens (or perhaps even more).

For this project, the students used different methods such as hypertext, manipulation of pictures and Digital Storytelling. The term "Digital Storytelling" is used for a phenomenon that started in California in the beginning of the1990s. The founders of the Center for Digital Storytelling, Dana Atchley, Joe Lambert and Nina Mullen, present digital storytelling as a special art-form of storytelling. Digital storytelling in this context is presented as short, linear and personal films expressed through digital media by ordinary people. It has the potential to be a very democratic kind of storytelling. Usually the story is between two- to three-minutes long. The storyteller uses still pictures and his/hers own voice to tell the story. The focus on the storyteller's own voice is something special in Digital Storytelling. The amateur way of telling makes the story often authentic, which engages people to engaging in the story Lambert et al, 2003) (see also www.storycenter.org).

Several of the students dealt with two specific subjects: the architecture of Lillehammer and what the authorities have to offer vis-à-vis young people's free time. With regard to architecture, the students wanted high-rise buildings ("skyscrapers"). Lillehammer is a small and charming city with a population of approximately 25,000 people, surrounded by beautiful countryside. Numerous 
tourists visit it every year. I interpret the youngsters' view as a wish to urbanize the city and to make the city attractive for young people. They want a city that is alive and not a museum for tourists. Even more important was the wish of a youth club. The youth felt excluded even from the city centre and on their wish-list was a place to stay - a place to be. In other words, an including room for living.

The second project went on for 3 weeks in the autumn of 2004. In this project, the students were only to use the Digital Storytelling technique, because I found this way to communicate most interesting. The students could decide the subject they wanted to cover themselves and this was very exciting because the students chose subjects that had never occurred to me.

The students made more than 20 stories, and they also produced their own website. Their stories featured transport problems, the legal rules related to operating a motorbike, the legal rules related to the age of active sexuality, the adults' views of youngsters, wolves inhabiting the surrounding countryside, injustice and many other issues. These topics are fairly different from one another, but one thing they do have in common: The topics proved to be important for the younger people of Lillehammer and are all linked to their daily lives. The students were deeply engaged in expressing themselves and also wanted other people to take part in the discussions.

I find the experience that I have had with these two projects fascinating.

\section{Concluding remarks}

My conclusion is that the production of media texts has a great potential to make the students think, reflect and develop their autonomy, especially Digital Storytelling, because of its media-rich content. The techniques of Digital Storytelling are easy to learn and the students find this way to express themselves exciting. If the students have access to computers, it is also very easy to implement in education programmes. Producing digital stories and publishing them on the Internet can be seen as process of instituting society and allow the student's imagination to be a contribution to a creative instituting of society.

The projects discussed in this paper were discussed at the conference in a PowerPoint presentation, which can be downloaded in the Appendix of this issue of Nordicum-Mediterraneum.

\section{References}

Buckingham, David (2003): Media education : literacy, learning and contemporary culture. Cambridge: Polity Press.

Buckingham, David (2000): After the death of childhood: Growing up in the age of 
electronic media. Cambridge, Polity Press.

Castells, Manuel (2001): The internet galaxy reflections on the internet, business, and society. Oxford, Oxford University Press

Castells, Manuel (2007): "Communication, Power and Counter-power in the Network Society”. International Journal of Communication 1: 238-266.

Castoriadis, Cornelius (2005): Figures of the thinkable including passion and knowledge. [Online] Retrieved from Internet 10.02.08

http://www.notbored.org/FTPK.pdf

Castoriadis, Cornelius (1997): The Castoriadis reader (CR). Oxford: Blackwell readers

Castoriadis, Cornelius (1997): World in Fragments (WIF). Writings on Politics, Society, Psychoanalysis, and the Imagination. California, Stanford University Press

Council of Europe (2008): Education for democratic citizenship and human rights (EDC/HRE). Learning and Living Democracy. [Online] Retrieved from Internet 14.09.08

http://www.coe.int/t/dg4/education/edc/What is_EDC/EDC_Q\&A en.asp

Engelstad, Fredrik, Guro Ødegård (2003): Ungdom, makt og mening. Makt- og demokratiutredningen (1998-2003). Oslo: Gyldendal Norsk Forlag AS

Haugen, Sidsel Pihl. (1995). Barn som medborgere: visjon og virkelighet. Master in ethnology, University in Bergen, Norway.

John, Mary (2003): Children's rights and power: Charging up for a new century. London New York, Jessica Kingsley Publishers.

Kress, Gunther (2003): Literacy in the new media age. London, Routledge.

Mikkelsen, Rolf, Dag Fjeldstad, Hein Ellingsen (2002). Demokratisk beredskap og engasjement hos elever i videregående skole $i$ Norge og 13 andre land: Civic Education Study Norge 2002. Oslo, Institutt for lærerutdanning og skoleutvikling, Universitetet i Oslo.

Mikkelsen, Rolf, Elisabeth Buk-Berge, Hein Ellingsen, Dag Fjeldstad, Annette Sund (2001). Demokratisk beredskap og engasjement hos 9.-klassiner i Norge og 27 andre land. Civic Education Study Norge 2001., Institutt for lærerutdanning og skoleutvikling. Universitetet i Oslo.

Miljøverndepartementet (1995): Rikspolitiske retningslinjer for barn og planlegging. 


\section{Nordicum-Mediterraneum}

[Online] Retrieved from Internet 14.09.08

\section{http://www.lovdata.no/cgi-wift/ldles?doc=/sf/sf/sf-19950920-4146.html}

Lambert, Joe, Nina Mullen, Paull Caleb, Emily Paulos, Thenmozhi Soundararajan (2003): Digital Storytelling. Cookbook and Travelling Companion. Version 4.o. Center for Digital Storytelling. Berkeley, California: Digital Diner Press. [Online] Retrieved from Internet 25.06.03 http://www.storycenter.org/cookbook.html

Lidén, Hilde (2003). “Ungdomsråd - politisk lekestue?” in Guro Ødegård and Fredrik Engelstad: Ungdom, makt og mening. Makt- og demokratiutredningen 1998-20o3. Oslo, Gyldendal akademisk, page: 93-120

Lidén, Hilde and Guro Ødegård (2002): Ungt engasjement: ungdoms samfunnsengasjement og lokalpolitiske deltagelse. Oslo, Norsk institutt for forskning om oppvekst, velferd og aldring

Norris, Pippa (2001): Digital divide civic engagement, information poverty, and the Internet worldwide. Cambridge, Cambridge University Press

Poster, Mark (1995): The second media age. Cambridge: Polity Press

Rowe, Dorothy. (1989). "Introduction" in J. Masson (1989): Against therapy. London:Collins. Quoted in Mary John: Children's rights and Powers in a Changing World (2003). Philadelphia , USA:Jessica Kingsley Publishers.

Rowe, Dorothy (1991): Wanting everything. London, HarperCollins

Straume, Ingerid Solrunsdatter (2008): Politikken og det imaginære. Cornelius Castoriadis' filosofiske bidrag til politisering av demokrati- og utdanningsfeltet. Doctoral thesis. Institute for Educational Research; University of Oslo. (Work in progress)

Wilkinson, Helen, Geoff Mulgan (1995): Freedom's Children: Work, Relationships and politics for 18 - 34 Year olds in Britain Today. London, Demos

White, Clarissa, Sara Bruce, Jane Ritchie (2000): Young people's politics. Political interest and engagement amongst 14-24 year olds. The National Centre for Social Research is Britain. The Joseph Rowntree Foundation. York: York Publishing Services Ltd. [Online] Retrieved from Internet 14.06.08 http://www.jrf.org.uk/bookshop/eBooks/1859353096.pdf

Websites:

www.storycenter.org 
www.ungisentrum.net

Birte Hatlehol is a PhD student in Media Education at the University of Science and Technology of Norway. Her doctoral thesis deals with education in democracy and how contemporary media can be used for the purpose of democratic education. She has a background as a social worker and video director, especially with regard to educational videos. She holds a master's degree in practical-theoretical film studies from the Department of Art and Media Studies of Norway's University of Science and Technology 